\title{
Challenges of Integrating GeoGebra in the Teaching of Mathematics in South African High Schools
}

\author{
Lindiwe G Mokotjo ${ }^{1, *}$, Matseliso L Mokhele ${ }^{2}$ \\ ${ }^{1}$ Faculty of Education, School of Mathematics Natural Science and Technology Education, University of Pretoria (RSA), South Africa \\ ${ }^{2}$ Faculty of Education, School of Educational Studies, University of the Free State (RSA), South Africa
}

Received February 2, 2021; Revised March 31, 2021; Accepted April 18, 2021

\begin{abstract}
Cite This Paper in the following Citation Styles
(a): [1] Lindiwe G Mokotjo, Matseliso L Mokhele, "Challenges of Integrating GeoGebra in the Teaching of Mathematics in South African High Schools," Universal Journal of Educational Research, Vol. 9, No. 5, pp. 963 - 973, 2021. DOI: 10.13189/ujer.2021.090509.
\end{abstract}

(b): Lindiwe G Mokotjo, Matseliso L Mokhele (2021). Challenges of Integrating GeoGebra in the Teaching of Mathematics in South African High Schools. Universal Journal of Educational Research, 9(5), 963 - 973. DOI: 10.13189/ujer.2021.090509.

Copyright $\odot 2021$ by authors, all rights reserved. Authors agree that this article remains permanently open access under the terms of the Creative Commons Attribution License 4.0 International License

\begin{abstract}
Technology is embraced as an integral part of modern society, and hence it is also important for education to integrate various aspects of technology into teaching and learning. The South African National Development Plan (NDP) also prescribes the inclusion of quality technology to enhance the classroom experiences of both teachers and learners. GeoGebra is one of the preferred mathematics software in South African high schools. This qualitative study explores the challenges of teachers in the integration of GeoGebra in the teaching of mathematics in South African high schools. Using interpretivism as a research paradigm, we listened to and recorded the views of teachers about challenges they experienced in the integration of GeoGebra. The data was elicited from four purposively selected teachers from the Bojanala District in the North West Province of South Africa by using unstructured interviews which were transcribed, coded and categorised into relevant themes. The selected teachers signed the consent forms as part of their willingness to participate voluntarily in the study. The study supports the view that teachers are pivotal factors in the integration of GeoGebra and hence the need to understand their challenges. The key finding revealed was that South African high schools were being robbed and vandalised of ICT equipment because of security issues. Further, each school owned only one data projector which stifles efforts to strengthen teachers' knowledge and skills in implementing the integration of GeoGebra into mathematics lessons. Consequently, this loss of equipment
\end{abstract}

disadvantages teachers and learners concerning the integration of GeoGebra into mathematics lessons because learners did not have computers for exploring and experimenting, and teachers are becoming demotivated due to insufficient resources and a lack of modern skills to make mathematics lessons interesting and productive.

Keywords Information and Communication Technology, Information and Communication Technology Integration, GeoGebra Software

\section{Introduction}

Modern society utilises technology that permeates almost every aspect of life. Therefore, the integration of technology into the education system is one way of dealing with the challenges in mathematics which will uplift the performance if applied skilfully and knowledgeably. Various studies investigate the integration of technology as part of the solution to address mathematics teaching and learning challenges [15]; [40]. The South African National Development Plan (NDP) also prescribes the inclusion of quality technology to enhance the classroom experience of both teachers and learners. This highlights the confidence placed in the integration of technology as a means through which mathematics education can be improved [51].

Mathematics software programmes are known to be 
advantageous as it encourages teachers to focus on specific mathematics topics, bring about dynamic movement, utilise sound and graphics to enhance learning by making a contribution to problem-solving tasks, practising number skills, and exploring patterns and relationships [59]. These assist learners with conceptualising and simplifying abstract ideas in mathematics which enhance their learning and improve academic results. GeoGebra is one of the mathematics software tools that is regarded as being effective in teaching mathematics, not only for better conceptual understanding, but also that it promotes a fun-learning atmosphere [57]. Understandably, the Ministry of Education in Australia has made GeoGebra software freely available at schools and universities since 2006. It has also been adopted by Florida Atlantic University in America for their mathematics project to enhance the teaching and learning of mathematics [33].

According to [54], in Trends in International Mathematics and Science Study (TIMSS), which is a mathematics assessment written by South African high school learners in Grade 9, South Africa is ranked among the weakest internationally, in terms of mathematics performance.

Hence, modern technology and other relevant software tools including GeoGebra should be used as part of the integration strategy in the teaching and learning of mathematics in order to upgrade performances. GeoGebra has been applied widely in South African high schools with research showing its use mainly in KwaZulu-Natal, Limpopo, and Gauteng [11];[16].This article identifies challenges experienced by teachers in South African high schools concerning the integration of GeoGebra into mathematics lessons.

Integrating technology into mathematics teaching-learning situations remains a challenge for teachers; and this emanates from a lack of teacher development in the use of technology [21];[7]. The other known challenges faced by teachers are inadequate infrastructure, limited number of computers, and other necessary resources [23]. In some instances, the teachers lack ICT skills, while some lack a positive attitude towards applying new forms of teaching in mathematics. These factors pose challenges on how technology can be successfully integrated into the education environment.

[67] contends that most schools in South Africa have ICT resources; however, these resources are mostly either underutilised or abandoned completely. [52] confirm that the challenge in the integration of technology in teaching is the lack of necessary skills in teaching in a manner that enhances learner performance. [10] adds that a lack of support from teachers' managers, and a lack of teacher confidence, have been some of the hindrances in the integration of technology. The United Nations Educational, Scientific and Cultural Organisation [66] advises that the accomplishment of technology-enhanced learning lies in the ability of the teacher to effectively integrate technology into classroom lessons. We, therefore, believe that teachers are critical in making technology operational in their classrooms in a manner that will benefit learners. Hence, this article seeks to understand the teachers' challenges in the integration of GeoGebra in South African high school mathematics teaching.

\section{Literature Review}

\subsection{Integration of Technology}

The general integration of ICT in learning has inspired teachers to create learning materials that are innovative and promote an active learning environment that is learner-centred. This promotes learning that is relevant to the development of learners with $21^{\text {st }}$ century skills [55]; [63]. The learner-centred teaching environment is the opposite of the traditional method ('talk-and-chalk') learning environment where the teacher and the textbook have been the central part of the learning process [16].

\subsection{Integration of GeoGebra in Teaching and Learning}

GeoGebra was designed by Markus Hohenwarter as an open - source dynamic mathematics software that incorporates geometry, algebra and calculus into a single, open - source, user - friendly package. GeoGebra was the subject of the master's thesis project of Markus Hohenwarter at the University of Salzburg in 2002 [34]; [33]. This software combined features of previous software programmes such as Maple, Derive, Cabri and Geometer's Sketchpad [56]. GeoGebra is a free and user - friendly programme that connects geometry and algebra [71]. [43] refers to GeoGebra as an interactive geometry, algebra, statistics and calculus application intended for learning and teaching mathematics from the primary level of education to university level. GeoGebra allows for the creation of interactive web pages that are used for the demonstration and experimentation of various mathematics concepts [30]. It is available on multiple platforms, with desktop applications for Windows, OS, Linux and Mac. It also has tablet applications for Android, Apple and Windows [43].

In a study conducted by [16] on the integration of GeoGebra software in teaching mathematics in high school, it was found that "the integration of information technology (IT), GeoGebra in particular, into teaching and learning of secondary school mathematics can serve as a scaffold on which changes and developments in curriculum can be better managed". However, it is also important to note that the integration of any ICT tools does not occur in a vacuum. Hence, [2] describes the commitment of the administration to support the school management which in turn should bolster up the teachers. The school management should also be directly involved in ensuring 
that the resources are available and in good working order.

Various countries have endorsed the integration of GeoGebra in the teaching of mathematics. In Slovakia, a study presented several possibilities of how GeoGebra might be integrated into education. GeoGebra is recommended for solving geometry tasks in the new Slovak curriculum for secondary schools [29].

In Malaysia, [53] studied the effects of using GeoGebra to teach students fractions. The study revealed that the use of GeoGebra to teach fractions is very effective. This was evident through the improved scores of the students in the experimental group. The findings highlighted that the students in the experimental group performed better than those in the control group who were taught using the traditional learning method. The software also enhanced visualisation and understanding of the concept of fractions for both the teacher and the students. Hence, GeoGebra is also endorsed in teaching geometry content in Malaysia [9].

A study conducted in Singapore on the innovative activities that could develop geometric reasoning skills assisted by the open-source software GeoGebra, found that students who were taught by using GeoGebra made good progress towards mathematical explanations, which provided a foundation for further deductive reasoning in mathematics. The conclusion was that the dynamic nature (drag feature) of the software influenced the form of explanation, and that the students were able to generate the solution and respond appropriately. Consequently, it was found that GeoGebra made the learning of abstract concepts far more meaningful as it helped to visualise related concepts [69].

In Indonesia, GeoGebra is also a mathematics tool of choice. [60] present an argument that GeoGebra is free software that includes algebra, geometry and calculus into one package, whereas other packages treat them separately. For example, analytical geometry is viewed as difficult by most students because it is abstract and needs to be solved using algebraic principles.

A study was conducted in Nigeria to examine the effects of GeoGebra software on the performance of high school learners in mathematics. Using random sampling, two classes were divided into two groups - an experimental group and a control group. The experimental group was taught using GeoGebra and the control group was taught using the conventional method. The findings showed that the learners who were taught via GeoGebra performed better than the control group [3].

A study conducted in South Africa in the Limpopo Province concerning the integration of GeoGebra in teaching linear functions in Grade 9, found that the learners who were taught with the use of GeoGebra outperformed the learners who were taught without GeoGebra. It was, therefore, recommended that teachers use GeoGebra as a tool as it is user-friendly and effective for planning lessons.

Similar studies conducted in KwaZulu-Natal to establish the impact of the integration of GeoGebra in the teaching of Euclidean geometry, established that learners who had been taught through the integration of GeoGebra performed better than those who had not been exposed to it [11]; [47]. These results indicate that GeoGebra facilitates the understanding of abstract concepts in geometry.

\subsection{Integration of GeoGebra in the South African Mathematics Curriculum}

In this section we explore relevant literature that links the effectiveness and relevance of GeoGebra in the South African high school curriculum. This will provide contextual evidence of the challenges faced by teachers in the integration of GeoGebra in terms of GeoGebra's value when applied to high school mathematics classroom settings.

\subsubsection{Effectiveness of GeoGebra in Algebra}

Functions refer to mathematics work that relates to the relationship between variables in terms of numerical, graphical, verbal and symbolic representations. Functions may be represented in the form of tables, graphs, words and formulas. The algebra section of the curriculum also encapsulates the investigation of algebraic expressions and the simplification of exponents. Learners have to understand the mathematical rules and language that are necessary for effective learning [22]. For example, when dealing with algebraic concepts, one needs to multiply the binomials (which has two terms e.g. $2 \mathrm{x}-2$ ). ${ }^{2 x}-2$

[48] investigated the effect of integrating GeoGebra in linear functions and found that learners who were taught linear functions using GeoGebra performed better than learners who were taught the same topic using 'chalk and talk'. [48] further attest that GeoGebra is effective in teaching linear algebra where the gradient and y intercept of a line may be investigated. Of great assistance, was [14] who designed various GeoGebra applications where teachers and learners can experiment and learn about solving quadratic equations.

\subsubsection{Effectiveness of GeoGebra in Euclidean Geometry and Measurement}

According to [22] the Euclidean geometry and measurement section in the FET Phase of the South African curriculum covers the investigation and forming of conjectures about the properties of special triangles (isosceles, equilateral and right-angled triangles e.g. a kite), quadrilaterals and polygons. Additionally, [17] designed a GeoGebra application that provides an illustration of teaching geometry concepts such as various properties of triangles using GeoGebra. GeoGebra assisted students when drawing sides of triangles and measuring the angles. For example, when dealing with a scalene triangle, it was clear that all sides and the interior angles were not equal.

Various studies have been conducted on the 
effectiveness of GeoGebra in teaching geometry. [68] found that learners taught via the use of the GeoGebra software made better progress in understanding mathematical explanations, which provides a foundation for further deductive reasoning in mathematics. Other researchers also illustrated the advantages of utilising GeoGebra in the understanding of Euclidian geometry specifically in lines, angles, triangles, and problem-solving skills [36]; [37]. Further, [74]; [57) illustrated the positive impact of understanding circles, and cylindrical and spherical coordinates through the integration of GeoGebra.

\subsubsection{Effectiveness of GeoGebra in teaching Trigonometry}

Using GeoGebra software for the section on Functions (high school trigonometry), a task is given as follows: Evaluate trigonometric functions of an angle given on its terminal ray [14].

According to [74] and [38] GeoGebra is effective in teaching trigonometric concepts with a special focus on periodicity of trigonometric functions.

It can be concluded that the integration of GeoGebra helps in creating a learning environment in which learners can discover, explore, conjecture, and visualise. It has the advantage of fostering conceptual understanding of abstract mathematics concepts included in the South African high school curriculum.

\subsubsection{Professional development (PD) in teaching and learning mathematics using ICT software}

Research highlights the teacher as being the most important component in the integration of ICT and ICT software in the teaching environment [71]. [69] recommends that teachers can gain knowledge of the integration of technology through ongoing professional development (PD) sessions relating to technology integration and classroom teaching-learning situations. This section explores the role of PD and how teachers are supported in the integration of ICT and ICT software in various parts of the world. Teacher PD should address the multiple forms of knowledge required for teaching, and involve the development of effective processes of knowledge management [69]. Other studies have emphasised the potential of PD and advised that it should be tailored to local conditions but included with global best practices [6]. Teacher-training courses, both pre- and in-service, can assist teachers who are apprehensive to move faster and adopt technology, while stepping up levels of ICT integration with more enthusiastic teachers [1].

\subsection{Challenges in the Integration of GeoGebra}

This section addresses the threats and challenges of integrating ICT in teaching mathematics. The literature relates to the challenges of integration and unpacks new perspectives and role- modelling strategies on how teachers can effectively integrate ICT tools in teaching mathematics in high schools. This study is focused on the integration of ICT software, specifically GeoGebra in the teaching of mathematics in high schools in SA. However, GeoGebra is used in conjunction with other software packages. Hence, it becomes relevant in this context to note the challenges with respect to ICT in general while specifically referring to GeoGebra software.

Challenges existing from the early period of the introduction of ICT in teaching and learning having been identified as far back as in 1999. The challenges were classified into first (external) and second (internal) order barriers [26]; [27]. First-order barriers are challenges associated with access to and support in using technology. Second-order barriers relate to teachers' beliefs on how ICT should be used in teaching and learning; and these include the pedagogical beliefs and classroom technology practices.

Three reports from countries that have a good record of mathematics performance according to TIMMS explore the first-order barriers for technology integration. In a case study from Indonesia, [41] refer to the lack of funding and inadequate support to staff. In China, a case study by [72] highlighted the acquisition of cutting- edge technologies in teacher education. In Combodia, [24] laments the lack of digital resources and infrastructure as first-order barriers in the integration of ICT. [64] identified an additional level of challenge (the third order) in the integration of ICT in teaching and learning that emerged from the work of [26] this refers to the teachers' pedagogical strategies and how they improve their teaching practice through technology.

In South Africa, a study by [46] on improving teachers' technological pedagogical content knowledge for teaching Euclidean geometry using mathematics software, observed challenges faced by teachers in the integration of ICT software which were: teachers' negative attitude towards lesson preparation, teachers' burdensome workloads, and access to ICT versus quality of ICT. [8] attest that teachers' challenges in the integration of ICT software, specifically in the teaching of science and mathematics, are linked to teachers' lack of training and skills to use these software tools. Further, unsuitable school environments, lack of resources, and teachers' reluctance, were the main barriers preventing the implementation of technology in education [42]; [62]. However, it was specifically highlighted that teachers' lack of confidence, set beliefs and attitudes towards the role of technology, and their ability of successfully implementing ICT modernity within schools, were more profound as barriers (Ibid).

[42] confirms that the introduction of ICTs in schools poses a major challenge in that ICT-based methods of teaching are resisted by teachers due to fear of change and lack of skills in incorporating the new ICT tools. Thus, when teachers lack the skills or feel intimidated by ICT tools, they tend to abandon the mathematics software and miss the opportunity to create interesting and innovative learning activities. 


\section{Methodology}

This article is part of a larger study that qualitatively explored the practices of four teachers in integrating GeoGebra in the teaching of mathematics in South African high schools. This study used all the participants from the bigger study to draw on their experiences in the integration of GeoGebra in the teaching of mathematics. According to [19], qualitative research empowers individuals to share their lived experiences. This study is aligned to the interpretivist methodological paradigm which is based on the principle that the researcher understands the meanings and interpretations of participants' own perspectives [28]. According to [50] the data collected under the qualitative research paradigm can be supportive in understanding the individual's views and opinions. We further employed a case study as the research design. According to [18], a case study is a "design of inquiry ... in which the researcher develops an in-depth analysis of a case, often a program, event, activity, process, or one or more individuals". We considered in detail the cases of four teachers, each as a separate case, and then performed an intra-case analysis. In order to collect the necessary data, four purposively selected teachers from the North West Province in South Africa were interviewed using recorded semi-structured interviews. The collected data was analysed using content analysis which is described by [25] a reflective process in qualitative research. The recorded interviews were therefore transcribed, coded and categorised into meaningful themes, mainly focusing on teachers who were using GeoGebra and received training to implement it in their mathematics teaching. All the participants were provided with informed consent forms which were signed as part of their pledge to participate voluntarily in the research.

\section{Findings and Discussions}

In this section, we present the findings of the study that emerged from the data. These findings will be presented through the following themes, school security to retain ICT tools; school environment; professional development and support in the integration of GeoGebra. The bibliographical data of the teachers who participated in the study is also presented in this section. Such data provides a brief background of each participant namely, Mr Magwe, $\mathrm{Mr}$ Sebaya, $\mathrm{Mr}$ Golenyane and Mr Maziya (all pseudonyms for confidentiality purposes). Lastly, the direct quotations from the participants are also included in this section to support the findings of the study.

- Magwe is a high school teacher with six years' experience in teaching mathematics, physical science and technology from Grades 8 to 12 . He holds a BSc in Computer Science and Electronics, a Postgraduate Diploma in Education, and Postgraduate Certificate in
Education (PGCE). He has been using other ICT tools and GeoGebra for 18 months

- Sebaya is a teacher with six years' experience in teaching mathematics, natural science and technology from Grades 8 to 13 in most provinces in South Africa. He holds a BEd Honours degree, a PGCE in Natural Science and Mathematics, and B. Comm Statistics degree. He has been using other ICT tools and GeoGebra for over a year.

- Golenyane is a teacher with nine years' experience in teaching mathematics, natural science and computer science. He holds a BSc Computer Science degree and a PGCE qualification. He has been using GeoGebra and other ICT software tools for six years.

- Maziya is a teacher with five years' experience in teaching mathematics and physical science in Grades 8, 10 and 12. He holds a BEd degree in Science and Mathematics, a BEd Honours degree in Physical Science, and is currently working on his MEd. He has been using other ICT tools and GeoGebra for over a year.

The themes that emerged from the study:

\subsection{School Security to Retain ICT Tools}

Literature has shown that, although South African schools received computers, tablets and e-Whiteboards from private donors and NGOs, these tools gathered dust as they remained unused by the schools [67]; [8]. The teachers who were interviewed expressed concern over security at their schools in terms of use and storage of ICT equipment. The data from this study further reveals that the ICT tools were either stolen or vandalised while on the school premises; this is in contrast to the predominant belief that ICT tools were there, but just not used. According to the participates, once stolen, these ICT tools were never replaced, thus the integration of ICT tools into teaching-learning is compromised. Additionally, [58] reports that some schools lock computers away in the storerooms where teachers and learners cannot use them because of fear of them being stolen instead of engaging better and fool-proof security strategies - this act stifles ICT integration. The integration of GeoGebra is further compromised because learners are deprived of the opportunity to explore GeoGebra independently. Participants unanimously related to learners' lack of ICT tools due to security issues. Magwe stated:

The computers were stolen from the lab. The interactive board was taken from the wall. It was bad... I think it's people who knew where we keep our technology. After that, learners did not have any computers. GeoGebra is wonderful but yooh! It's sometimes challenging to use it because sometimes you want learners to practise using GeoGebra but they can't. 
Maziya reiterated that his school lacked resources because of the theft of ICT tools such as computers. He added that it was frustrating because no one was ever held accountable for such an act, even after reporting it to the authorities.

Maziya indicated:

You know Mam... all computers were stolen from this school. But no one was arrested. This school is so close to the community. You want to tell me that no one saw anything?

Golenyane also expressed concern that ICT tools such as interactive whiteboards were vandalised.

It's a shame. Last Friday.... They had cut the power supply to the smartboard. But, I can't connect because I don't have a power supply to the smartboard. They have cut the cables and the power supply.

As indicated by (44) The interactive whiteboard is one of the valuable ICT tools because it is versatile in its use. With the interactive whiteboard, learners are able to actively engage with the content, receive instant feedback on what they are working on, and manipulate the learning objects. The interactive whiteboard would also blend well with GeoGebra. For example, many chances to interact with the whiteboard were missed even just to observe and experiment with the features in GeoGebra.

Sebaya shared similar sentiments expressing the view that the absence of computers was affecting his attitude towards using GeoGebra for teaching. He indicated that he was reluctant to use GeoGebra in his mathematics lessons because learners lacked access to computers. Sebaya shared that:

... [I]t would be nice if learners can have computers.

Maybe if we had a computer lab because we could have a lesson and learners can do some work on GeoGebra. They could do a classwork task. I think that it would be interesting.

From the above quotations, it is clear that the loss of ICT tools through theft and vandalism is a challenge to the integration of ICT, especially to GeoGebra. GeoGebra would be more beneficial if learners have an opportunity to experiment with the mathematics concepts themselves. [4] concur that the learning environment and lack of ICT resources directly impact on the integration of ICT in the teaching and learning of mathematics. [20] further confirm that the absence of technology from schools compromises the learners' degree of success in the $21^{\text {st }}$ century. Participants reflected on the theft of computers as the main compromising factor in the integration of any form of technology in the teaching and learning of mathematics. This reflected on the weakness of the security systems, which was exacerbated by the lack of insurance for ICT equipment. Hence, when these valuable items were stolen or vandalised, there was no replacement. Teachers and learners had to return to traditional teaching methods seeing that ICT tools were lacking; and this situation demoralised teachers and learners and affected their attitude towards ICT integration into mathematics lessons.

\subsection{School Environment: Management Support}

The commitment of the school administration members is an important factor in the facilitation of ICT integration. [5] describes this commitment as the support that school management needs to give to teachers. (5) further adds that school management must procure and ensure that the resources are in good working order and that teachers have the skills to use them, in addition to making tight security arrangements for the safe storage of equipment.

In this study, we found that in all participants' schools, teachers had only one projector to use for the entire school. All teachers who participated in this study had access to a projector and laptop with some indicating to owning either a tablet or smart cell phone that they also used as part of their teaching and learning programmes. The teachers who we interviewed indicated that they preferred using the projectors when integrating GeoGebra into their mathematics lessons. However, the schools had only one projector each and that meant that at times it would not be available when required. Magwe highlighted that:

We have one projector that we share with other teachers. It is a projector for the whole school. If the Economics teacher needs it .... he uses it. Physics teacher needs it... he uses it. We used to have the interactive whiteboard that was in the lab. Yooo... learners enjoyed working on it.

The excerpt above indicates the limitations of having one projector equipment per school. This indicates that even if the teacher plans a lesson that incorporates GeoGebra through using the projector, there would be no guarantee that the same lesson will take place as planned. This kind of uncertainty would be demotivating to teachers who are keen on introducing the integration of GeoGebra as well as other ICT tools in their teaching of mathematics. Magwe mentioned that he found value in using of the projector but the challenge as mentioned earlier, was that there was only one projector. He lamented:

You know, Mam, the projector has changed learning in class. At least now, I can download videos or use videos that were donated to the schools and learners can watch these videos. We have one projector that we share with other teachers. It is a projector for the whole school. If the Economics teacher needs it .... he uses it. Physics teacher needs it... he uses it. We used to have interactive white board that was in the lab. Yooo... learners enjoyed working on it.

Magwe, as indicated in the above extract, expressed his willingness to integrate ICT tools into his lessons. However, with limited resources, such as one projector for the entire high school, the demoralising element comes into 
play; and this thwarts the efforts and enthusiasm of teachers who are willing to integrate GeoGebra into their teaching-learning classroom situations. This situation would therefore require the support from the school management. As indicated by [2] the school management needs to procure and ensure that the resources are in good working order and that teachers have adequate skills to use them.

\subsection{Lack of Professional Development (PD) and Support in the Integration of GeoGebra}

The professional development (PD) of teachers is a crucial process for the successful integration of ICT in teaching and learning. [30] postulates that teacher development, which is focused on the training of teachers, specifically on how teachers can integrate ICT in the mathematics, is a necessity. This study established that teachers were given GeoGebra software with minimal support and there was no relevant person to contact whenever they experienced challenges. This is in agreement with [35] who emphasises that there is a need to upgrade teacher-training policies and programmes in developing countries. It is however appalling how all the four teachers who were interviewed for the purpose of this study could not remember the officer from the Department of Education who offered them training for GeoGebra. All these teachers referred to him as the 'guy' who offered GeoGebra training. This was a strong indication of the lack of a relationship and communication between the teachers and the officials who are responsible for the training of teachers in the integration of GeoGebra. Magwe confirmed:

The challenges that I have, honestly, I wish that the guy could come back again. Yes, because though we did try to introduce some concepts of skills or whatever, I feel it was not enough. We were looking at the laptop, all of us so I wish he would come back for us to learn more things.

Golenyane also experienced similar frustrations as Magwe concerning training opportunities relating to GeoGebra:

I can say, I never received any training in GeoGebra. The guy from the Department of Education came. He showed us briefly, how we can integrate GeoGebra. I can't call that training. It was too quick. But I could follow because I knew GeoGebra.

Magwe reiterated that the last time (and first) they saw the Department of Education official was when he came to introduce GeoGebra to them.

The last time we saw the guy from the Department was when he came to show us the software. No one has said anything since then.

Maziya was also of the view that the GeoGebra training was not adequate enough to prepare them to integrate
GeoGebra in the teaching of mathematics with confidence. Maziya added:

You know... it will be nice if that guy who gave us GeoGebra can come again. Just show us what this can do....I don't like using it (GeoGebra) sometimes because I am not sure of what I want to do.

From the above quotation it became evident that due to the minimal training on the integration of GeoGebra, Maziya was not confident in integrating it in the teaching mathematics.

Magwe also shared the same thoughts that even though he believed GeoGebra was a good mathematics teaching tool, he was sometimes reluctant to use it because he believed he needed more training to be able to use GeoGebra with confidence. He responded:

I can say GeoGebra is good and is free but it is difficult because no one showed us properly how to use if for this and for that. There are somethings that I want to do using GeoGebra but yoo ... I struggle and then I just leave it.

Sebaya also had a similar experience. He believed that he only knew less than half of what he believed he needed to know about GeoGebra:

But, I know less than $50 \%$ of what I can do with GeoGebra. If I can see myself being able to draw my own diagrams, any diagram, then I would say that I am satisfied.

Sebaya complained that the GeoGebra training which was done in the principal's office was haphazard and lasted a couple of minutes. He added:

Hey we were busy that day, we were busy and I don't remember whether it was a meeting or what but it was very busy and the principal was like just go to him for a few minutes and then he just gave us pointers there and there. So, it wasn't really a training session and we didn't do much. We just crowded around the laptop and the gentleman just went through the whole thing quickly.

Golenyane also had minimal training that was conducted in the principal's office, and he said:

We received very little training in using GeoGebra. If we can have more training .... The training happened in the principal's office.

Maziya shared the same sentiments:

The Department sent someone to train us for GeoGebra. It was one hour training in the principal's office. The trainer came and we were called to the principal's office. We were told he has come to show us the software that will help in teaching mathematics. It was a quick thing. He showed us to click on a few pages. Input some equations. I'm not sure if I could call that training. Then left the information package that was 


\section{downloaded on our laptops.}

From the above extracts, we note a brief and weak execution of training sessions concerning the integration of GeoGebra which had no follow-up. However, the lack of management support was evident as the only training received was held in the principal's office. There was no intervention from the management for comprehensive training to take place. As such, there is a need for further research to establish the involvement of management in the integration of GeoGebra. ICT as a tool alone does not translate to success in academic subjects. Teacher development which is focused on the training of teachers, specifically on how teachers can integrate ICT in the teaching of mathematics is fundamental [31]. In fact [61] concurs that commitment and school culture are some of the important elements in facilitating the integration of ICT in the teaching and learning environment. The lack of professional development and support poses a serious hindrance in developing teachers' skills, and creating a positive attitude towards the integration of GeoGebra into mathematics lessons.

\section{Conclusion}

With the high failure rate in high school mathematics, the integration of ICT tools and mathematics software is becoming increasingly valued as an intervention tool in upgrading performances in mathematics. Mathematics is misconstrued as being as abstract, and boring to most learners. With the advent of GeoGebra, a solution to the problem has been found; but it must be remembered that teachers are central to the success or the failure of the integration of ICT tools including GeoGebra. The evidence from the biographical information of the selected teachers in this study shows that they are qualified and experienced in teaching high school mathematics as they all hold appropriate degree qualifications together with postgraduate qualifications. However, there are challenges in the integration of GeoGebra, which are all valid. GeoGebra is a kind of mathematics software that requires some level of mathematics knowledge as well as the experience and skill in using other related ICT tools and software.

Furthermore, data from this study shows that the aspect of school security posed a challenge in the integration of GeoGebra because this resulted in the shortages of ICT resources. The integration of GeoGebra in a classroom requires at least the computer, projector and ideally the e-whiteboard. Moreover, most of these schools have limited resources which leave learners with limited access to computers to practice and enhance their independent learning. Teachers' attitude and the lack of resource availability negatively affected the delivery of GeoGebra integration. The teachers in this study indicated that they preferred using the projector when integrating GeoGebra into their mathematics lessons. However, the schools had only one projector each, and it meant that at times the projector would not be available when required.

To add to the woes of integration, teachers received 'training' that only lasted about an hour. The department of education sent someone from the District, and the official downloaded the software and briefly showed how the software works. However, they saw the value of GeoGebra and independently learnt how to use it in their mathematics lessons.

There was also evidence to confirm that the lack of professional development and support was compromising the integration of GeoGebra. There is an urgent need to strengthen teachers' development and support mechanisms for the effective integration of GeoGebra. [13] recommend the provision of "cognitive support for teachers who may have, self-perceived, negative reaction to GeoGebra" as a necessary step towards the informed and viable use of GeoGebra to improve teaching and learning in mathematics. All these challenges are not insurmountable as a concerted effort and will to succeed are the ingredients to make GeoGebra integrate cohesively with mathematics teaching and learning.

Other countries call for the integration of GeoGebra into their curriculum. Such countries recommend a good understanding of GeoGebra, how to teach it and support offered to teachers so that they are better equipped to use GeoGebra in teaching and learning [53];[50]. There is therefore a need to have professional training which is focused on the integration of GeoGebra for South African high school. [65] strongly recommends better professional development of teachers to boost their readiness to integrate technology and to increase their willingness to design mathematics activities and learning strategies with technology.

The shortage of resources due to security, school management inadequacy and insufficient professional development are being cited as the major challenges in the integration of GeoGebra. There is a need for a reformed policy that tackles the security issues to deal decisively with theft and vandalism. There is a further need for policy reform on the actual curriculum, namely that it should include the integration of GeoGebra. In addition, the policy should strengthen the professional development of teachers to be able to integrate ICT software better in their teaching.

\section{REFERENCES}

[1] Abuhmaid, A. ICT training courses for teacher professional development in Jordan. Turkish Online Journal of Educational Technology, Vol.10, No.4, pp.195-210, 2011.

[2] Al Achhab Sakina, E. J. Z. Integration of ICT in teaching mathematics. Conference Paper presented at " 1 st International Annual Interdisciplinary Conference”. Azores, 
Portugal. 24 -26 April 2013.

[3] Akanmu, I. A. Effect of GeoGebra Package on learning outcomes of Mathematics (secondary school) students in Ogbomoso North Local Government Area of Oyo State, Nigeria. Master's Thesis. Obafemi Awolowo University, Ile-Ife, Nigeria, 2015.

[4] Akbulut, Y., Odabasi, H. F. \& Kuzu, A. Perceptions of preservice teachers regarding the integration of information and communication technologies in Turkish education faculties. Turkish Online Journal of Educational Technology, Vol.10, No. 3, pp. 175-184, 2011.

[5] Al Achhab Sakina, E.J.Z. Integration of ICT in teaching mathematics. European Scientific Journal, 9(19). https://doi.org/10.19044/esj.2013.v9n19p\%25p Date of access: 3 Jan. 2021, 2013.

[6] Albion, P. R., Tondeur, J., Forkosh-Baruch, A. \& Peeraer, J. Teachers' professional development for ICT integration: Towards a reciprocal relationship between research and practice. Education and Information Technologies, Vol. 20 No.4, 655-673, 2015.

[7] Alharbi, A. M. Teacher's Attitudes towards Integrating Technology: Case Studies in Saudi Arabia and the United States. Graduate Research and Creative Practice. Masters Thesis. 58, 2013.

[8] Assan, T. \& Thomas, R. Information and communication technology integration into teaching and learning: Opportunities and challenges for commerce educators in South Africa. International Journal of Education and Development using Information and Communication Technology, Vol.8, No. (2), pp. 4-16, 2012.

[9] Azizul, S. M. J. \& Din, R. (2018). Teaching and learning mathematics of geometry using GeoGebra software via MOOC. Journal of Personalized Learning, Vol.2, No.1, pp.40-51, 2018.

[10] Banas, J. R. Teachers' attitudes toward technology: Considerations for designing preservice and practicing teacher instruction. Community \& Junior College Libraries, Vol.16, No. 2, 114-127, 2010.

[11] Bayaga, A., Mthethwa, M. M., Bosse, M. J. \& Williams, D. (2019). Impacts of implementing GeoGebra on eleventh grade student's learning of Euclidean Geometry. South African Journal of Higher Education, Vol. 33, No.6, pp. 32-54, 2019.

[12] Berežný, Š. (2015). What software to use in the teaching of mathematical subjects? Acta Didactica Napocensia, Vol. 8, No.1, pp. 75-85, 2015.

[13] Bu, L., Mumba, F., Henson, H. \& Wright, M. 20 13. GeoGebra in professional development: The experience of rural in-service elementary school $(\mathrm{K}-8)$ teachers. Online Submission, Vol. 3, No. 3, pp. 64-76 (2013).

[14] Brzezinski, T. GeoGebra. https://www.GeoGebra.org/searc h/algebra\%20expression. [accessed 14 August 2020], 2017.

[15] Chigona, A., Chigona, W., Kausa, M. \& Kayongo, P. An empirical survey on domestication of ICT in schools in disadvantaged communities in South Africa. International Journal of Education and Development Using ICT, Vol.6, No.2, pp 21-32, (2010).
[16] Chimuka, A. The effect of integration of GeoGebra software in the teaching of circle geometry on grade 11 students' achievement. Unpublished Doctoral Thesis. University of South Africa, Pretoria, 2017

[17] Choong, J. \& Hale, M. Copy of properties of equilateral, isosceles, and scalene triangles equilateral, isosceles and scalene triangles. https://www.GeoGebra.org/m/hyzzdayj [accessed 15 March 2019], 2017

[18] Cresswell, T. Place: An introduction. Hoboken, NJ: John Wiley \& Sons, (2014)

[19] Creswell, J. W. \& Poth, C. N. Qualitative inquiry \& research design: Choosing among five approaches (4th ed.). Los Angeles: SAGE, 2018.

[20] Culatta, R. \& Adams, B. Learning technology effectiveness. US Department of Education Office of Educational Technology. http://tech. ed. gov/learning-technology-effecti veness [Accessed 23 March 2020], 2014

[21] Davidson, L. Y. J., Richardson, M., \& Jones, D. Teachers' perspective on using technology as an instructional tool. Research in Higher Education Journal, Vol. 24, No. , pp. 1 25. (2014)

[22] Department of Basic Education [DBE]. Curriculum and Assessment Policy Statement Grades 10-12, Mathematics. Pretoria: Government Printer, 2011.

[23] De las Peñas, M. L. A. N. \& Baustista, D. The Emerging Role of GeoGebra in the Philippines. Model-Centered Learning, Vol. 6, pp.217-219, 2011.

[24] Dionys, D. (2012). Introduction of ICT multimedia into Cambodia's teacher training centers. Australasian Journal of Educational Technology, Vol 28, No. 6, pp. 1068-1073, 2012).

[25] Erlingsson, C. \& Brysiewicz, P. (2017). A hands-on guide to doing content analysis. African Journal of Emergency Medicine, Vol 7, No. 3, pp.93-99, (2017).

[26] Ertmer, P.A. Addressing first- and second-order barriers to change: Strategies for technology integration. Educational Technology Research and Development, Vol. 47, No. 4, pp. 47-61, 1999.

[27] Ertmer, P.A., Ottenbreit-Leftwich, A.T., Sadik, O., Sendurur, E. \& Sendurur, P. (2012). Teacher beliefs and technology integration practices: A critical relationship. Computers \& Education, Vol,.59, No. 2, pp. 423-435, 2012.

[28] Goldkuhl, G. (2012). Pragmatism vs interpretivism in qualitative information systems research. European journal of information systems, Vol. 21, No. 2, pp. 135-146, 2012.

[29] Gunčaga, J., Majherova, J. \& Jancek, M. GeoGebra as a motivational tool for teaching and learning mathematics and physics. Ruzomberok, Slovakia: Scientific Issues, MATHEMATICA1V, 2012.

[30] Hismanoglu, M. (2012). The impact of a curricular innovation on prospective EFL teachers' attitudes towards ICT integration into language instruction. International Journal of Instruction, Vol.5, No.1, pp. 183-202, 2012.

[31] Hohenwarter, M., \& Lavicza, Z. The strength of the community: How GeoGebra can inspire technology 
integration in mathematics. In: L. Bu \& R. Schoen (Eds.). Model-Centered Learning: Pathways to mathematical understanding using GeoGebra (pp. 7-12). Rotterdam: Sense Publishers, 2011

[32] Hohenwarter, M. \& Lavicza, Z. The strength of the community: How GeoGebra can inspire technology integration in mathematics teaching. MSOR Connections, Vol. 9, No.2,pp. 3-5, 2009.

[33] Hohenwarter, M. \& Preiner, J Creating mathlets with open-source tools. Journal of Online Mathematics and its Applications, 7 (July). Article ID 1574, 2007.

[34] Hohenwarter, M., Hohenwarter, J., Kreis, Y., \& Lavicza, Z. Teaching and learning calculus with free dynamic mathematics software GeoGebra. In: 11th International Congress on Mathematical Education. Monterrey, Nuevo Leon, Mexico. 6 -16 July, 2008.

[35] Jansen, J.D. Political symbolism as policy craft: Explaining non-reform in South African education after apartheid. Journal of Education Policy, Vol 17, No. 2, pp. 199-215, 2010

[36] Jelatu, S., Sariyasa, S., \& Ardana, I. M. (2018). The effect of integrating GeoGebra software towards understanding of geometry concepts in terms of students' spatial ability. Jurnal Pendidikan dan Kebudayaan Missio, Vol 10, No. 2, pp. 162-171, 2018.

[37] Khalil, M., Sultana, N., \& Khalil, U. Exploration of mathematical thinking and its development through GeoGebra. Journal of Educational Research, Vol. 20, No. 1, pp. 83-99, 2017.

[38] Kepceoglu, I. Teaching a Concept with GeoGebra: Periodicity of Trigonometric Functions. Educational Research and Reviews, Vol. 11, No. 8, pp. 573-581, 2016

[39] Leask, M. \& Younie, S. National models for continuing professional development: the challenges of twenty-first-century knowledge management. Professional development in education, Vol. 39, No. 2, pp. 273 -287, (2013)

[40] Leendertz, V., Blignaut, A. S., Blignaut, H. D., Els, C. J. \& Ellis, S. M. (2013). Technological pedagogical content knowledge in South African mathematics classrooms: A secondary analysis of SITES 2006 data. Pythagoras, Vol. 34, No. 2, pp. 1-9, 2013.

[41] Lim, C. P. \& Pannen, P. (2012). Building the capacity of Indonesian education universities for ICT in pre-service teacher education: A case study of a strategic planning exercise. Australasian Journal of Educational Technology, Vol. 28, No. 6, pp. 1061-1067, 2012.

[42] Magen-Nagar, N. \& Peled, B. Characteristics of Israeli schoolteachers in computer-based learning environments. Journal of Educators Online, Vol. 10, No. 1, pp. 1-34, 2013.

[43] Majerek, D. Application of GeoGebra for teaching mathematics. Advances in Science and Technology Research Journal, Vol. 8, No. 24, pp. 51-54, 2014

[44] Manny-Ikan, E., Dagan, O., Tikochinski, T. \& Zorman, R. Using the interactive white board in teaching and learning an evaluation of the smart classroom pilot project. Interdisciplinary Journal of E-Learning and Learning
Objects, Vol. 7, No. 1, pp. 249-273, 2011.

[45] Mdlongwa, T. Information and communication technology (ICT) as a means of enhancing education in schools in South Africa: Challenges, benefits and recommendations. AISA Policy Brief, Vol. 80, pp. 1-8, 2012.

[46] Mosia, M. S. Improving teachers' technological pedagogical content knowledge for teaching Euclidean geometry using integrated information communication technologies software. Unpublished Doctoral Thesis. University of the Free State, Bloemfontein, 2016.

[47] Mthethwa, M. Application of GeoGebra on Euclidean geometry in rural high schools - Grade 11 learners. Doctoral Thesis. University of Zululand, Ngoya, 2015.

[48] Mudaly, V., \& Fletcher, T. (2019). The Effectiveness of GeoGebra when Teaching Linear Functions using the IPad. Problems of Education in the 21st Century, Vol. 77, No.1, 2019.

[49] Mushipe, M. \& Ogbonnaya, U. I. GeoGebra and grade 9 learners' achievement in linear functions. International Journal of Emerging Technologies in Learning, Vol. 14, No. 8, pp. 206-219, 2019.

[50] Myers, M. D. Qualitative research in business management. London: Sage, 2019.

[51] National Planning Commission. (2012). National Development Plan 2030. "Our future - make it work". Pretoria: Government Printer, 2012.

[52] Ndlovu, N. S. \& Lawrence, D. The quality of ICT use in South African classrooms. Conference Paper presented at "Towards Carnegie III Strategies to Overcome Poverty and Inequality. Cape Town, South Africa. 3 - September 2012.

[53] Noorbaizura, T. \& Leong, K. E. Effects of students' achievement in fractions using GeoGebra. Malaya: University of Malaya Press, 2013.

[54] Reddy, V., Zuze, T. L., Visser, M., Winnaar, L., Juan, A., Prinsloo, C. H., Arends, F., \& Rogers, S. Beyond benchmarks: What twenty years of TIMSS data tell us about South African education. Pretoria: HSRC Press, 2015 .

[55] Saavedra, A. R. \& Opfer, V. D. Learning 21st century skills require 21st century teaching. Phi Delta Kappan, Vol. 94, No. 2, pp. 8-13, 2012.

[56] Saha, R. A., Ayub, A. F. M., \& Tarmizi, R. A. The effects of GeoGebra on mathematics achievement: enlightening coordinate geometry learning. Procedia - Social and Behavioral Sciences, Vol. 8, pp. 686-693, 2010.

[57] Shadaan, P. \& Eu, L. K. (2013). Effectiveness of using GeoGebra on Students' Understanding in Learning Circles. The Malaysian Online Journal of Educational Technology, Vol. 1, No. 4).

[58] Sedibe, M. Inequality of access to resources in previously disadvantaged South African high schools. Journal of Social Sciences, Vol. 28, No. 2, pp. 129-135, 2011.

[59] Sivakova, D., Kochoska, J., Ristevska, M. \& Gramatkovski, B. (2017). ICT - The Educational programs in teaching mathematics. TEM Journal Technology, Education, 
Management, Informatics, Vo. 6, No. 3, pp. 469-478, 2017.

[60] Sudihartinih, E. \& Purniati, T. Using Geogebra to develop students understanding on circle concept. Journal of Physics [Conference Series], Vol. 1157, No. 4, pp. 1-7, 2019

[61] Tay, L.Y., Melwani, M., Ong, J.L. \& Ng, K.R. A case study of designing technology-enhanced learning in an elementary school in Singapore. Learning: Research and Practice, Vol. 3, No.2, pp. 98-113, 2017.

[62] Thomas, M. O. \& Palmer, J. M. Teaching with digital technology: Obstacles and opportunities. In: Clark-Wilson, A., Robutti, O., \& Sinclair, N. (Eds.). The mathematics teacher in the digital era (pp. 71-89). Dordrecht: Springer, 2014.

[63] Tindowen, D. J. C., Bassig, J. M. \& Cagurangan, J. A. Twenty-first-century skills of alternative learning system learners. Sage Open, Vol.7, No. 3, pp.1-8, 2017

[64] Tsai, C. C. \& Chai, C. S. The "third"-order barrier for technology integration instruction: Implications for teacher education. Australasian Journal of Educational Technology, Vol. 28, No. 6, pp. 1057-1060, 2012.

[65] Umameh, M.A. The potential of the joint use of GeoGebra and interactive whiteboard for teaching and learning straight line graphs. Unpublished master's dissertation. University of Bristol, Bristol, BS8 1TR.

[66] UNESCO. ICTs for curriculum change. Paris: UNESCO, 2012.

[67] Van Wyk, Education in South Africa: Is ICT the answer? National Science and Technology Forum. htpp://www.nstf.co.za [Accessed 12 November 2020],
2014.

[68] Venkataraman, G. Innovative activities to develop geometrical reasoning skill in Secondary mathematics with the help of open resource software "GeoGebra". National Conference on Mathematics Education, Mumbai, 20-22, 2012

[69] Watson, C. L. The use of technology in secondary mathematics classrooms: The case of one school district. Unpublished Master's Thesis. The University of Southern Mississippi, Hattiesburg, MS, 2015.

[70] White, J. (2012). The impact of technology on student engagement and achievement in the mathematics classroom. Unpublished Master's Thesis. Memorial University, Christchurch, New Zealand, 2012.

[71] Xu, Y. Beyond access: Helping teachers integrate technology into classrooms wisely. http://isilearn.net/helpin g-teachers-integrate-technology-into-classrooms/ [Accessed 14 August 2020], 2017.

[72] Yan, H., Xiao, Y., \& Wang, Q. Innovation in the educational technology course for pre-service student teachers in East China Normal University. Australasian Journal of Educational Technology (special issue), Vol. 28 No. 6, pp. 1074-1081, 2012.

[73] Yildiz, A., \& Baltaci, S. Reflections from the Analytic Geometry Courses Based on Contextual Teaching and Learning through GeoGebra Software. Online Submission, Vol. 6, No. 4, pp.155-166, 2016.

[74] Zengin, Y., Furkan, H., \& Kutluca, T. The effect of dynamic mathematics software geogebra on student achievement in teaching of trigonometry. Procedia-Social and Behavioral Sciences, Vol.31, pp.183-187, 2012. 